DOI:10.31696/2072-8271-2020-1-1-46-356-369

\title{
Why South China Sea is Important for the Philippines: Economic Aspect
}

\section{Daria S. Panarina}

$\mathrm{PhD}$ in Culturology, Researcher, Center for Southeast Asia, Australia and Oceania, Institute of Oriental Studies, RAS, Russia, Moscow, daria2002panarina@gmail.com, https://orcid.org/0000-0003-3756-4056

Abstract: South China Sea in the Southeast Asia region has always been and remains a strategic and economic factor of the balance among many regional states as well as some outer players, including here the USA and China. To answer a question why for many states in the region, states always growing economically the SCS is a water area of great significance, what is so important in the sea for regional economies and outer states - is the main purpose of this paper. The author gives data on the riches of the SCS and explains its role as a water way for transporting oil through the region. Growing oil demand in the ASEAN countries is also examined in this work in order to speculate on possible perspectives on oil market in the region in the future.

Keywords: South China Sea, oil, reserves, demand, marine resources, transportation, liquefied natural gas

\section{Почему Южно-Китайское море важно для Филиппин: Экономический аспект}

\section{Панарина Дарья Сергеевна}

кандидат культурологии, научный сотрудник Центра ЮВА, Австралии и Океании ИВ РАН, Россия, Москва, daria2002panarina@gmail.com, https://orcid.org/0000-0003-3756-4056

Аннотация: ЮКМ в регионе ЮВА всегда было и остается стратегическим и экономическим фактором баланса между многими странами региона, а также внешними игроками, включая США и Китай. Найти ответ на вопрос, почему для многих государств ЮКМ является акваторией большой значимости; что особенно важно в данном море для региональных экономик и других стран - вот главная цель этой работы. Автор приводит данные о природных богатствах ЮКМ и объясняет его роль как морского маршрута для перевозки нефти через регион. Исследуется ситуация с растущим спросом на нефть среди стран АСЕАН, дается прогноз о положении на нефтяном рынке региона в будущем.

Ключевые слова: Южно-Китайское море, нефть, запасы, спрос, морские ресурсы, перевозки, сжиженный природный газ

(C) Панарина Д.С., 2020. 
South China Sea, Chinese Nan Hai is an arm of the western Pacific Ocean that borders the Southeast Asian mainland. It is bounded on the northeast by the Taiwan Strait (by which it is connected to the East China Sea); on the east by Taiwan and the Philippines; on the southeast and south by Borneo, the southern limit of the Gulf of Thailand, and the east coast of the Malay Peninsula; and on the west and north by the Asian mainland. The South China Sea and the East China Sea together form the China Sea. The southern boundary of the South China Sea is a rise in the seabed between Sumatra and Borneo, and the northern boundary stretches from the northernmost point of Taiwan to the coast of Fujian province, China, in the Taiwan Strait. It embraces an area of about $1,423,000$ square miles $(3,685,000$ square $\mathrm{km})$, with a mean depth of 3,976 feet (1,212 metres) ${ }^{1}$.

South China Sea has long been a matter of territorial conflict among the countries of the South-East Asia region including Brunei, the People's Republic of China (PRC), Republic of China (Taiwan), Malaysia, Indonesia, the Philippines, and Vietnam. For all of the countries participating in the dispute South China Sea is as important as is balance and peace in the region itself. There are three main reasons why South China sea is so crucial for all the member-countries in the region. Different researchers claim that some of these reasons are more important, whereas others are not so much significant, but I personally would say that they are all equally essential. All of them are mostly economical and not political and engrave the matter of resources (hydrocarbons and fisheries) and the matter of commercial marine lanes that is more a strategical reason. Nonetheless, all three are interconnected.

And here I am going to mostly speak of the economic reasons, namely of the demand for oil and natural gas in the ASEAN countries in terms of their constantly growing economies and so constantly growing demand for resources in general. According to Economic Research Institute report published in 2018 and covering the time period starting with year 2015 oil demand in the Association of Southeast Asian Nations (ASEAN) is expected to grow rapidly for the foreseeable future. At 4.4 million barrels per day $(\mathrm{mb} / \mathrm{d})$ in 2015 , oil demand in the region is projected to increase by $4.1 \%$ per year to reach $12.2 \mathrm{mb} / \mathrm{d}$ in 2040 , according to the Economic Research Institute for ASEAN and East Asia (ERIA, 2016). The biggest growth will happen in Indonesia, where demand will increase by $4.8 \%$ per year to reach $4.8 \mathrm{mb} / \mathrm{d}$ in 2040 . Thailand will see a steady increase in demand too, with an annual growth rate of $4.5 \%$ to reach $2.3 \mathrm{mb} / \mathrm{d}$, while Malaysia will have annual growth of 
$3.0 \%$ to reach $1.7 \mathrm{mb} / \mathrm{d}$ in 2040 . Singapore also shows strong demand growth, at $4.0 \%$ per year, though it will plateau at about $0.8 \mathrm{mb} / \mathrm{d}$ from 2030 onward. Demand in other countries in the region will grow significantly, but the share of these four countries will remain at about $80 \%$ until 2040. By contrast, regional production is expected to decline steadily towards 2040. ASEAN countries produced $2.9 \mathrm{mb} / \mathrm{d}$ of crude in 2015 . With $0.8 \mathrm{mb} / \mathrm{d}$, Indonesia is the largest producer in the region, followed by Malaysia $(0.7 \mathrm{mb} / \mathrm{d})$ and Thailand $(0.5 \mathrm{mb} / \mathrm{d})$. ASEAN production, according to The Institute of Energy Economics, Japan (IEEJ) estimates, is likely to decrease to $2.1 \mathrm{mb} / \mathrm{d}$ in 2040 . The region's import dependency was $44 \%$ in 2015 , which is already significant, and it could rise to $83 \%$ in $2040^{2}$.

In this situation where the demand for oil is expected to grow and regional production of oil to decrease, all the countries mentioned and others are going to face a necessity to either import oil from overseas or to look for new reserves in the region itself. That is where the South China Sea with its undiscovered but presumably large amounts of oil and gas comes in sight.

It is difficult to determine the amount of oil and natural gas in the South China Sea because of under-exploration and territorial disputes. Most current discovered fields cluster in uncontested parts of the sea, close to the shorelines of the coastal countries. EIA estimates there to be approximately 11 billion barrels (bbl) of oil reserves and 190 trillion cubic feet (Tcf) of natural gas reserves in the South China Sea. These numbers represent both proved and probable reserves, making them closer to a high-end estimate. Energy consultancy Wood Mackenzie, for example, estimates the sea to contain only 2.5 billion barrels of oil equivalent in proved oil and gas reserves.

In addition to proved and probable reserves, the South China Sea may have additional hydrocarbons in underexplored areas. The U.S. Geological Survey (USGS) analyzed the potential for undiscovered conventional oil and gas fields within several geologic provinces of Southeast Asia in 2010 as part of its World Petroleum Resources Assessment Project. The study included a significant area of the South China Sea, which as the USGS estimates may contain anywhere between 5 and 22 billion barrels of oil and between 70 and 290 trillion cubic feet of gas in as-yet undiscovered resources (not including the Gulf of Thailand and other areas adjacent to the South China Sea). These additional resources are not considered commercial reserves at this time because it is unclear how economically feasible it would be to extract them. 
As the USGS assessment did not examine the entire area, undiscovered resources could be greater. In November 2012, the Chinese National Offshore Oil Company (CNOOC) estimated the area holds around 125 billion barrels of oil and 500 trillion cubic feet of natural gas in undiscovered resources, although independent studies have not confirmed this figure ${ }^{3}$. It is already known that oil and gas reserves in the South China Sea are not of the same amount and quality and differ greatly depending on where exactly on the shelf plate they are situated. For instance, according to EIA estimates the region around the Spratly Islands has virtually no proved or probable oil reserves. Industry sources suggest less than 100 billion cubic feet (Bcf) in currently economically viable natural gas reserves exist in surrounding fields. However, the Spratly Island territory may contain significant deposits of undiscovered hydrocarbons. USGS assessments estimate anywhere between 0.8 and 5.4 (mean 2.5) billion barrels of oil and between 7.6 and 55.1 (mean 25.5) Tcf of natural gas in undiscovered resources.

Evidence suggests that most of these resources are likely located in the contested Reed Bank at the northeast end of the Spratlys, which is claimed by China, Taiwan, and Vietnam. The Philippines began exploring the area in 1970 and discovered natural gas in 1976. U.S.-based Sterling Energy won the concession in 2002, and U.K.-based Forum Energy acquired the concession in 2005 and became its operator. However, Chinese objections halted further development, and the concession remains undeveloped.

At the same time the Paracel island territory does not have significant discovered conventional oil and gas fields and thus has no proved or probable reserves. Geologic evidence suggests the area does not have significant potential in terms of conventional hydrocarbons ${ }^{4}$.

Asia's robust economic growth boosts demand for energy in the region. The U.S. Energy Information Administration (EIA) projects total liquid fuels consumption in Asian countries outside the Organization for Economic Cooperation and Development (OECD) to rise at an annual growth rate of 2.6 percent, growing from around 20 percent of world consumption in 2008 to over 30 percent of world consumption by 2035 . Similarly, non-OECD Asia natural gas consumption grows by 3.9 percent annually, from 10 percent of world gas consumption in 2008 to 19 percent by 2035. EIA expects China to account for 43 percent of that growth.

With Southeast Asian domestic oil production projected to stay flat or decline as consumption rises, the region's countries will look to new 
sources of energy to meet domestic demand. China in particular promotes the use of natural gas as a preferred energy source and set an ambitious target of increasing the share of natural gas in its energy mix from 3 percent to 10 percent by 2020. The South China Sea offers the potential for significant natural gas discoveries, creating an incentive to secure larger parts of the area for domestic production ${ }^{5}$.

Among the countries involved in the conflict there are those for which access to energy resources is mostly crucial and one of these countries is the Philippines which claim significant portions of the water body of the sea and 8 of Spratly Islands. The Philippines generates about a third of the electricity for its main island of Luzon from a single source, the Malampaya gas field, which is expected to cease production by 2024 . Unless an alternative is found - and Reed Bank is the only good option currently on the table - the Philippines will need to either import significant amounts of natural gas at greater costs, rapidly incorporate other energy sources into its power supply, or face severe shortages $^{6}$. Shell operates the Malampaya gas platform located in the northern Palawan basin in a joint venture with Chevron and the Philippine National Oil Company (PNOC). Commercial drilling began in October 2001 with a reserve base of 2.7 Tcf and 85 million barrels of condensate. It is the flagship project of the country's Department of Energy and provides power for domestic use.

The Philippines had begun exploring the Reed Bank area of the Spratly Islands in the 1970s and successfully tested a gas well in 1976. Before commercial drilling began, Chinese protests forced the operation to shut down? ${ }^{7}$.

It is worth saying that as one of quickly developing countries in the regions, still with a whole sack of its own problems, the Philippines need all the resources they can get in order not only to further develop their economy, but to also improve the level of living in the country. The Philippines desperately need credit for building infrastructure, fighting corruption, establishing good governance and just providing the more than $100 \mathrm{mln}$ population with decent living conditions all over the country. Needless to say, that it is not only a matter of budget, but also time and arrangement, however, the Philippines need to have steady energy resources of their own to answer the country's demands at least partially. Otherwise they will have to buy energy resources overseas and that is not what they can afford on a regular basis, I would say. It is also important to remember that expenses on oil imported from overseas cannot be stable due to oil price fluctuations on the world market. 
According to the stats from the Department of Energy of the Philippines in 2018 total crude oil import for the period reached $41,747 \mathrm{MB}$, an increase of 15.9 percent from $36,016 \mathrm{MB}$ of $1 \mathrm{H} 2017$. About ninety percent of the total crude mix $(37,497 \mathrm{MB})$ was sourced from the Middle East, of which 37.7 percent (15,754 MB) came from Saudi Arabia, the top supplier of crude oil into the country. Next is Kuwait with a 24.6 percent share of the total crude mix, followed by UAE, Qatar and Oman with 18.6, 6.2 and 2.6 percent share, respectively. On the other hand, a total of $401 \mathrm{MB}$ was imported from the ASEAN Region (350 MB) and from local production (51 MB). Also, 3,849 $\mathrm{MB}$ of crude oil was sourced from Russia which is equivalent to 8.4 percent share of the total crude mix. The remaining 0.9 percent was from Taiwan (319 MB) and South Korea (31 MB). Product import mix comprised mostly of diesel oil at 39.8 percent, gasoline at 17.8 percent, LPG at 15.3 percent, kerosene/avturbo at 10.1 percent, fuel oil at 6.0 percent and other products at 11.1 percent share in the total product mix. Total gasoline import reached 41.1 percent of gasoline demand while diesel oil import was 51.5 percent of diesel demand. LPG import on the other hand, was 70.5 percent of LPG demand. Total product import was 54.3 percent of the total products demand. In general, for the first half of year 2018 crude oil production was about half less the existing demand ${ }^{8}$.

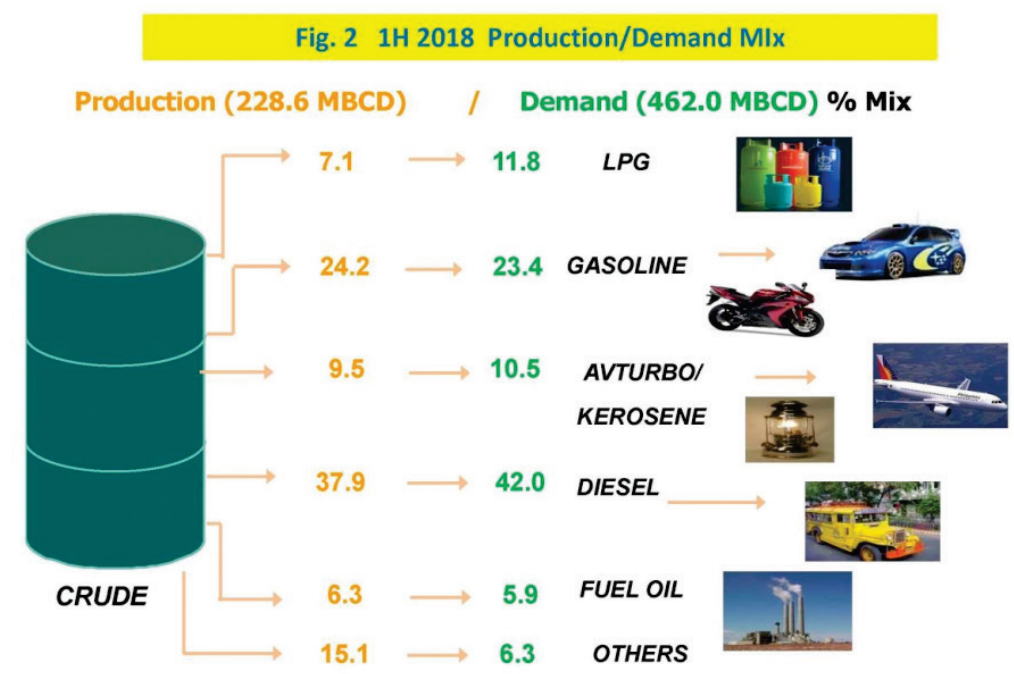

Numerous industries consume oil and oil products in different types of oil fuel and sub-products. In its report on designated energy statistics for year 2017 the DOE gives the full account of the industries petroleum demand, where the total for gasoline, kerosene, diesel, fuel oil, LPG and jet kerosene comes to 66.640 .461 barrels $^{9}$. Needless to mention that oil and oil-based products are used in all possible spheres. So, it is 
definitely of great significance for the Philippines to have stable oil resources.

No less important for the Philippines and in this matter - mostly for ordinary people - are the fishery resources in the disputed waters, first of all because they provide many people with food and jobs.

The South China Sea is rich in marine life. Contributing to this abundance are the extensive runoff of nutrient-laden waters from land and the upwellings of water in certain areas of the sea. The sea is heavily fished, however, and is the main source of animal protein for the densely populated Southeast Asian area. Most abundant are the various species of tuna, mackerel, croaker, anchovy, shrimp, and shellfish. Nearly the entire catch is consumed locally, either fresh or preserved ${ }^{10}$.

The area holds at least 3,365 species of marine fish, 55 per cent of global marine fishing vessels operate in the South China Sea, and some 12 per cent of global fishing catches take place here (2015 data). Moreover, for fringe states, fish is an extremely important source of nutrition, and fisheries employ at least 3.7 million people and likely many more engaged in illegal, unregulated, and unreported fishing. The region is host to rich fishing grounds supplying hundreds of millions of people across the region with food and jobs ${ }^{11}$.

Speaking of the Philippines in particular it is one of the major fishproducing countries and much of its fishery production is consumed locally. As of 2012 fishing industry of the Philippines involved 627 thousand people working in the sphere (not only in the SCS) and $116959^{12}$ marine vessels used in the industry. It is the second place in numbers after China among the countries of the region ${ }^{13}$.

According to most recent data from year 2019 fisheries production improved by 1.5 percent. Total volume of production was estimated at 4,421.22 thousand metric tons, higher than the 4,356.87 thousand metric tons reported a year ago. Of the three subsectors, outputs from municipal fisheries and aquaculture went up by 1.5 percent and 2.3 percent, respectively. Meanwhile, commercial fisheries production registered a decline of 0.7 percent.

By species, the major contributors to the increase were seaweed $(1.5 \%)$, milkfish $(3.7 \%)$, tilapia $(0.03 \%)$, skipjack $(5.2 \%)$, roundscad $(11.8 \%)$, yellowfin tuna (3.9\%) and tiger prawn (2.5\%). All of them displayed production increments from their 2018 level of production.

The annual volume of commercial fisheries production was registered at 940.00 thousand metric tons, lower by 0.7 percent than the 
946.44 thousand metric tons output in 2018. Commercial fisheries comprised 21.3 percent of the total fisheries output.

Production from municipal fisheries during the year was recorded at $1,122.88$ thousand metric tons, which was 1.5 percent higher than the previous year's output of $1,106.07$ thousand metric tons. Of its total volume of production, 86.1 percent was credited to marine municipal fisheries while the rest were catch from inland bodies of water. Municipal fisheries contributed 25.4 percent to the total fisheries production.

During the year, the total aquaculture produce was 2,358.33 thousand metric tons. Aquaculture posted an increase of 2.3 percent from its previous year's level of 2,304.37 thousand metric tons. Its production recorded the largest share of 53.3 percent to the total fisheries production $^{14}$.

It is necessary to say that the statistics cannot be very accurate as it does not account illegal, unreported and unregulated fishing.

South China Sea gives a big part of this catch but this vital marine ecosystem is seriously threatened by overfishing, which is encouraged by government subsidies, harmful fishing practices ${ }^{15}$, and, in recent years, large-scale clam harvesting and dredging for island construction ${ }^{16}$. Total fish stocks in the South China Sea have been depleted by $70-95$ percent since the 1950s and catch rates have declined by 66-75 percent over the last 20 years. Giant clam harvesting, dredging, and artificial island building in recent years severely damaged or destroyed over 160 square kilometers, or about 40,000 acres, of coral reefs, which were already declining by 16 percent per decade. The entire South China Sea fishery, which employs millions of people and helps feed hundreds of millions, is now in danger of collapse unless claimants act urgently to arrest the decline ${ }^{17}$. In order to restrain overfishing and regulate it in the future there have been introduced suggestions on formulating a plan or codex which would contain rules on fishing in SCS obligatory for all interested parts. Still, as this also implies a sort of agreement among the countries in the territorial conflict, it can take quite a lot of time to work out such kind of codex. Moreover, we cannot forget that in general one of the main characteristics of the politics in the South East Asia region is a tendency to solve conflicts through a process of discussions and negotiations, mostly in bilateral form, and that usually take quite a time as it is. So, there is a big question now as well, whether there will be any marine fish resources left in the SCS by the time all the countries agree on one system. 
Another problem which is strategically important for all the claimants and non-surprisingly for the outer forces such as the US which are much interested in the region and the SCS as well, is that the waters of the sea also serve as water ways for trade vessels. The South China Sea functions as the throat of the Western Pacific and Indian oceans, it is where numerous global sea routs coalesce. More than half of the world's annual merchant fleet tonnage passes through the South China Sea waters, and a third of all maritime traffic worldwide.

The oil transported through the Malacca Strait from the Indian Ocean, en route to East Asia through the South China Sea, is triple the amount that passes through the Suez Canal and fifteen times the amount that transits the Panama Canal. Roughly two thirds of South Korea's energy supplies, nearly 60 per cent of Japan's and Taiwan's energy supplies, and 80 per cent of China's crude oil imports come through the South China Sea. Whereas in the Persian Gulf only energy is transported, in the South China Sea it comes to energy, finished goods, and unfinished goods ${ }^{18}$.

Eastbound maritime trade through the South China Sea passes through the Straits of Malacca, Sunda, and Lombok. In 2006 Japan's Ministry of Land, Infrastructure, and Transport (MLIT) estimated that almost 94 thousand vessels of 100 gross tonnage or greater passed through the Strait of Malacca in 2004 out of 607 thousand global ocean vessel movements, or 15 percent of the world's total. That included 32 percent of container vessels, 25 percent of tanker vessels, 15 percent of cargo vessels, and 15 percent of bulk carriers among others.

In late 2007 another survey estimated 117 thousand vessels would pass through Malacca in 2010 with a total deadweight of 4.7 billion metric tons. The United Nations Conference on Trade and Development (UNCTAD) Review of Maritime Transport 2011 estimated 8.4 billion tons of total world maritime trade in 2010. This volume suggests more than half of the world's annual merchant fleet tonnage passed through the Straits of Malacca, Sunda, and Lombok in 2010.

As a rout for energy resources in particular the South China Sea is gravely significant. And in perspective with Asia's growing energy demand, EIA expects a greater share of oil from producers in the Persian Gulf and Africa to pass through the South China Sea.

Speaking of crude oil, approximately 14 million barrels pass through the South China Sea and Gulf of Thailand per day, that is about a third of global oil movement, according to data from Lloyd's List Intelligence tanker-tracking service and GTIS Global Trade Atlas. Over 90 
percent of the total flow comes from the Strait of Malacca, while the rest comes from intra-Southeast Asia regional trade.

A significant amount of crude arriving in the Strait of Malaca (1.4 $\mathrm{MMbbl} / \mathrm{d}$ ) goes to terminals in Singapore and Malaysia, where it is processed and shipped out again as refined petroleum products. Next, the rest of the flow (12.8 million MMbbl/d) continues on through the South China Sea to China and Japan (4.5 and 3.2 MMbbl/d, respectively), the two largest energy consumers in Asia. Finally, around 15 percent of oil moving through the South China Sea goes on to the East China Sea, mostly to South Korea. Crude oil flow in the South China Sea also comes from Intra-Southeast Asia regional trade, mostly from Malaysian (0.4 MMbbl/d), Indonesian (0.3 MMbbl/d), and Australian (0.2 $\mathrm{MMbbl} / \mathrm{d})$ oil exports and is approximately equally distributed between Singapore, South Korea, Japan, and China, with smaller amounts going to other Southeast Asia countries.

As for liquified natural gas, EIA estimates that around 6 trillion cubic feet (Tcf) or over half of global LNG trade, passed through the South China Sea in 2011, using data from PFC Energy and Cedigaz. Around 56 percent of this volume (3.4 Tcf) were imported to Japan, 24 percent to South Korea (1.4 Tcf), 19 percent to China and Taiwan (0.6 and $0.6 \mathrm{Tcf}$ respectively), and the rest to other regional countries. The biggest exporter through the sea was Qatar with 1.2 Tcf. Together, Qatar, Malaysia, Indonesia, and Australia accounted for almost 75 percent of all LNG exports to the region.

Following the Fukushima crisis, Japan increased its LNG imports. In the first half of 2012, the South China Sea area accounted for about 58 percent of global LNG trade, according to data from PFC Energy ${ }^{19}$. Needless to say, that apart from critical situations such as Fukushima crisis, rapidly developing economies in the region will further provoke the need in energy resources, both in export and import processes.

We can easily see that this prospect is true to life just looking through the latest available data. According to the publication from the same source in 2016 (as the most recent full year information I was able to find) more than $30 \%$ of global maritime crude oil trade, or about 15 million barrels per day (b/d), passed through the South China Sea.

More than $90 \%$ of crude oil volumes flowing through the South China Sea in 2016 transited the Strait of Malacca, the shortest sea route between suppliers in Africa and the Persian Gulf and markets in Asia, making it one of the world's primary oil transit chokepoints. In addition, a significant amount of crude oil (about 1.4 million b/d) passes through 
the strait on its way to Singapore and the west coast of Peninsular Malaysia, where it is refined before transiting the South China Sea in the form of petroleum products.

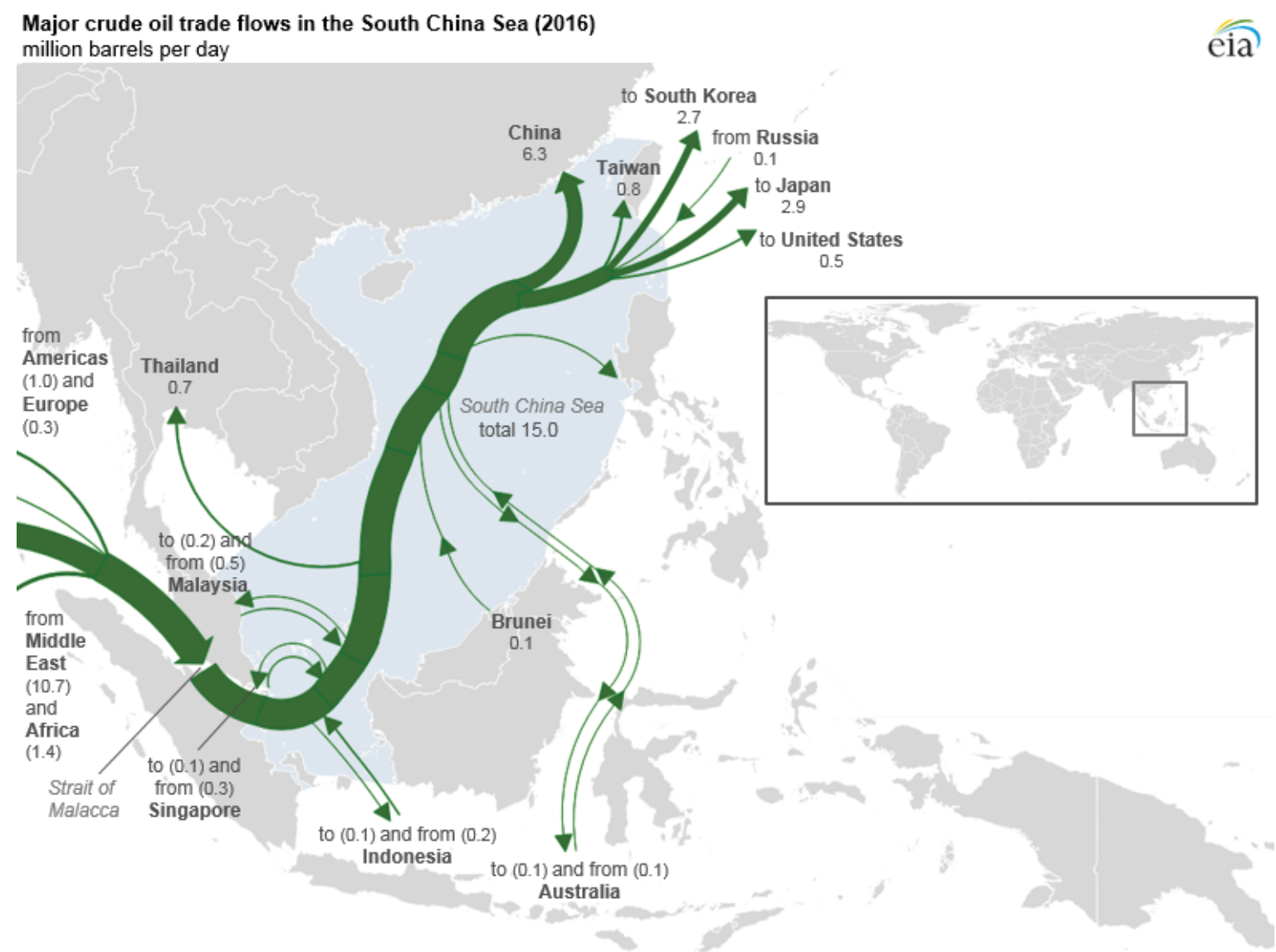

Source: U.S. Energy Information Administration, based on Clipper Crude Data Service and IHS EDIN. Total includes small flows (less than 0.1 million barrels per day) not shown on map.

The South China Sea is a major trade route for the Middle East, which accounted for more than $70 \%$ of total South China Sea crude oil shipments in 2016. Saudi Arabia is the largest source of crude oil, making up almost one-fourth of crude oil volumes traversing the South China Sea. More than half of Saudi Arabia's global crude oil shipments traveled through the South China Sea in 2016.

Before the lifting of United Nations sanctions on Iran's crude oil exports in January 2016, Iran relied heavily on Asian markets for most of its exports. After the sanctions were lifted, Iran could once again export crude oil to Europe. However, the South China Sea route still accounted for 52\% of Iran's crude oil exports in 2016.

In addition to Middle Eastern and North African volumes, some regional countries bordering the South China Sea contribute to the overall shipments of crude oil through the region. Indonesia and Malaysia 
together accounted for $5 \%$ of crude oil loadings that passed through the South China Sea in 2016 and $2 \%$ of crude oil receipts. Most of the crude oil from these countries that passes through the South China Sea is exported to other countries. However, some intra-country trade also crosses the southern portion of the South China Sea as cargoes move between eastern and western ports within each country.

Singapore accounted for $2 \%$ of crude oil loadings that passed through the South China Sea in 2016 and 1\% of crude oil receipts. Although Singapore does not produce crude oil, it is a major hub for refining crude oil and for storing and transshipping crude oil and petroleum products. In 2016, 95\% of Singapore's crude oil exports passed through the South China Sea. Most of these volumes originally came from the Middle East, and about half went to China.

The three crude oil importers with the largest volumes passing through the South China Sea-China, Japan, and South Koreacollectively accounted for $80 \%$ of total crude oil volumes transiting the South China Sea in 2016. About 90\% of China's 2016 maritime crude oil shipments were transported through the South China Sea. China's crude oil imports have increased substantially over the past few years as a result of the country's robust energy demand growth and stagnant crude oil production, and the country recently surpassed the United States as the world's largest crude oil importer. A significant portion of these incremental volumes that are sent to northern China from eastern Russia by pipeline and by shipping vessels does not pass through the South China Sea.

About $90 \%$ of the crude oil imported by Japan and South Korea was shipped through the South China Sea in 2016. Most of Japan's and South Korea's imports are from Middle Eastern suppliers and are transported through the Strait of Malacca and then the South China Sea (see the diagram $)^{20}$.

It is quite clear that to stabilize and preserve the rights to use the routes through South China Sea for oil and oil products transporting is an essential task for many countries of the region as well as for the outer "players" also interested in the possibility to further transfer their energy exports and imports the same way. In this case privileges and preferences given to only one or just several of the countries can lead to a most unfavorable and unpeaceful situation in the whole region. 
South China Sea crude oil trade flows (2016)

total trade: 15 million barrels per day

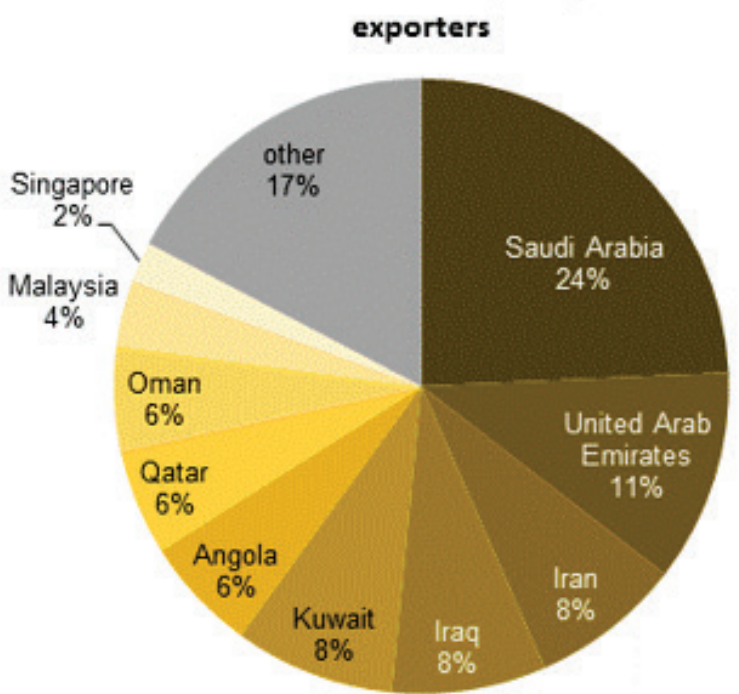

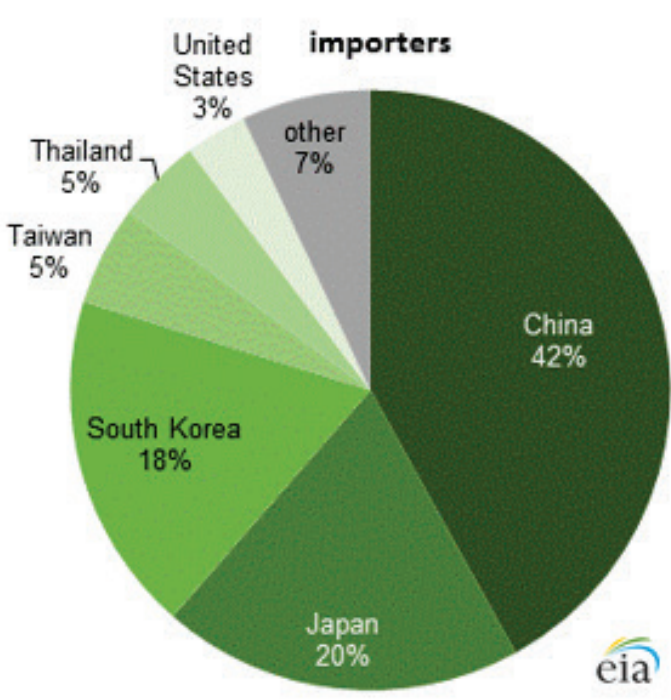

Source: U.S. Energy Information Administration, based on Clipper Crude Data Service.

For the Philippines the matter of free access to the trade marine routs in the South China Sea both for the country itself and for the other "players" in the region is a matter of two main points: general balance in South East Asia and availability of exports/imports of all kinds of goods, not only the hydrocarbons.

As the country which was originally colonized and ruled by Spain for almost 300 years, and then dominated by the USA with their democratic standards and economic experience, the Philippines have long been one of the most European-like country in the South East Asia region, both in its "looks" and development process. However, there are a lot of factors which are still preventing the Philippines from developing with their full potential as a pro-European state. Judging by what one can see in the streets of Manila nowadays, it being the biggest, the wealthiest and the most crowded city in the country, I think it is plausible to say that the Philippines still have a long way to go. Just looking at the photos, taken by me personally in September 2018 while on a business trip, makes me think, that the Philippines need all the finance and all the resources they can get as much as good governance in the country in order to catch up with their neighbor-states.

\footnotetext{
${ }^{1}$ China Sea. / Encyclopedia Britannica. URL: https://www.britannica.com/place/China-Sea

${ }^{2}$ Potential of Oil Stockpiling at Oil Terminals in Southeast Asia / ERIA Research Project Report 2017, \# 04. Ed. By Shigeru Kimura, Tetsuo Morikawa. Economic Research Insti-
} 
tute for ASEAN and East Asia, 2018. P. 1. URL: https://www.eria. org/uploads/media/ERIA_RPR_2017_04.pdf

${ }^{3}$ South China Sea. / U.S. Energy Information Administration. February 7, 2013. URL: https://www.eia.gov/beta/international/analysis_includes/regions_of interest/South_China_Sea/south_china_sea.pdf

${ }^{4}$ South China Sea. / U.S. Energy Information Administration. February 7, 2013...

${ }^{5}$ South China Sea. / U.S. Energy Information Administration. February 7, 2013...

${ }^{6}$ A Blueprint for Cooperation on Oil and Gas Production in the South China Sea. / Asia Maritime Transparency Initiative. July 25, 2018. URL: https://amti.csis.org/a-blueprint-forcooperation-on-oil-and-gas-production-in-the-south-china-sea/

${ }^{7}$ South China Sea. / U.S. Energy Information Administration. February 7, 2013...

${ }^{8}$ Oil Supply/Demand Report 1H 2018 Vs 1H 2017. / Department of Energy. URL: https://www.doe.gov.ph/downstream-oil

${ }^{9}$ Petroleum Demand by Industry. / Department of Energy. 2017. URL:

https://www.doe.gov.ph/sites/default/files/pdf/energy_statistics/2017-energy-designatedstatistics.pdf

${ }^{10}$ Eugene C. LaFond. South China Sea. / Encyclopedia Britannica. URL:

https://www.britannica.com/place/South-China-Sea

${ }^{11}$ Fish, not oil, at the heart of the South China Sea conflict. / Fridtjof Nansen Institute. 24.10.2017. URL: https:/www.fni.no/news/fish-not-oil-at-the-heart-of-the-south-chinasea-conflict-article1556-330.html

12 The figure consists of 115,303 municipal boats and 1,656 commercial vessels. Municipal boat count is based on 2000 data; commercial vessel numbers are based on 2007 data.

Source: BFAR (2012).

${ }^{13}$ U. Rashid Sumaila, William W.L. Cheung. Boom or Bust. The Future of Fish in the South China Sea. URL: https://drive.google.com/file/d/0B_oUJE4kCTZrb

VI4N2tTVjlpYTA/view P. 8.

${ }^{14}$ Fisheries Situation Report, January to December 2019 / Philippine Statistics Authority. January 30, 2020. URL: https://psa.gov.ph/content/fisheries-situation-report-januarydecember-2019

${ }^{15}$ Part of which is a necessity for small fishers who have to survive in rivalry with foreign corporations and investors in the industry in order to pay for the costs and still get some profit. More about it read in: Blitz Amy. Marina Fishing in the Philippines. Cultural Survival Quarterly Magazine. URL: https://www.culturalsurvival.org/publications/culturalsurvival-quarterly/marine-fishing-philippines

${ }^{16}$ A Blueprint for Fisheries Management and Environmental Cooperation in the South China Sea. / Asia Maritime Transparency Initiative. September 13, 2017. URL:

https://amti.csis.org/coc-blueprint-fisheries-environment/

${ }_{17}^{17}$ A Blueprint for Fisheries Management and Environmental Cooperation...

${ }^{18}$ Robert D. Kaplan. Why the South China Sea is so crucial / Business Insider. February 20, 2015. URL: https://www.businessinsider.com.au/why-the-south-china-sea-is-socrucial-2015-2

${ }^{19}$ South China Sea. / U.S. Energy Information Administration. February 7, 2013...

${ }^{20}$ More than $30 \%$ of global maritime crude oil trade moves through the South China Sea / U.S. Energy Information Administration. August 27, 2018. URL:

https://www.eia.gov/todayinenergy/detail.php?id=36952

Статья поступила в редакцию 09.04.2020, принята к публикации 23.04.2020. 